Acta vet. scand. 1987, 28, 135-141.

From the Department of Food and Environmental Hygiene and

the Department of Biochemistry, College of Veterinary Medicine, Helsinki, Finland.

\title{
The Effect of Combined Iron-Selenium Treatment on Erythropoiesis and Weight Gain of Piglets
}

\author{
By Timo Pekkanen, Paul Lindberg and Satu Sankari
}

\begin{abstract}
Pekkanen, T., P. Lindberg and S. Sankari: The effect of combined iron selenium treatment on erythropoiesis and weight gain of piglets. Acta vet. scand. 1987, 28, 135-141. - Ten sows were during their last month of gestation and first 4 weeks of lactation kept on a low Se ratio $(0.014 \mathrm{ppm}$ Se). Their $1-3$ days old piglets $(\mathrm{n}=$ 108) were divided in 2 groups, the experimental and the control group. Blood samples were taken from the piglets before the age of 3 days. Each of the piglets of the experimental group $(n=54)$ was treated subcutaneously in connection with the blood sampling with $200 \mathrm{mg} \mathrm{Fe}{ }^{+3}$ as iron dextran and $0,30 \mathrm{mg} \mathrm{Se} e^{+4}$ as sodium selenite (Pigfer-Se, Orion Corporation Ltd., Orion Pharmaceutica, Espoo, Finland). The piglets of the control group $(n=54)$ were correspondingly treated with $200 \mathrm{Fe}^{+3}$ as iron dextran. Blood samples were again taken 7, 14 and 28 days after the first sample.

The results showed that the mean increase in the number of erythrocytes during the first 7 days was significantly higher in the experimental group than in the control group $(p=0.006)$. No significant differences between the whole groups could be found in the later blood samples.

When some haematological parameters of those of the piglets of the experimental and the control group, which before the age of 3 days had the whole blood $\mathrm{Se} \leqq 55$ $\mu \mathrm{g} / \mathrm{l}$ were compared ( $\mathrm{n}=16$ and $\mathrm{n}=22$ respectively) the mean increase in the number of erythrocytes was found to be significantly higher both at 7 days and 14 days in the low Se piglets of the experimental group than the corresponding means of the control group ( $p=0.005$ and $p=0.016$ respectively). At 28 days the difference between the means was not significant.

The weekly mean weight gains of the low Se piglets of the experimental group were consistently higher at the successive weekly weighings than the corresponding means of the control group.
\end{abstract}

swine; haematology; RBC; PCV; GSHPx.

\section{Introduction}

The work of Sankari (1985) suggested that if 2 day old piglets born to sows kept on selenium (Se) deficient diets, are treated with iron $(\mathrm{Fe})$ and $\mathrm{Se}$, haemoglobin $(\mathrm{Hb})$ and haematocrit (PCV) values increase more in successive weekly blood samples than the cor- responding values of their littermates treated with iron only.

A recent study (Pekkanen et al. 1987) showed that the range of the whole blood Se concentrations is relatively wide in newborn piglets born to sows with $0.1 \mathrm{mg} / \mathrm{kg}$ added $\mathrm{Se}$ in the feed during gestation. The number 
of erythrocytes (RBC) increased more during a 2 week period in piglets with higher whole blood Se status than in piglets with lower Se status. The piglets in the study were not treated with $\mathrm{Se}$. The aim of the present work was to study the effect of combined Fe-Se treatment of newborn piglets on the development of some haematological parameters and weight gain during the first 4 weeks of life as compared to Fe treatment only.

\section{Material and methods}

Ten finnish Landrace sows at a commercial swinery were, during the last months of gestation and the first 4 weeks of lactation, fed a selenium-deficient diet (Tables 1 and 2). The analyzed Se content of the ration was $0.014 \mathrm{ppm}$. A total of 111 piglets were born.

Table 1. Diet of sows during last month of gestation and first four weeks lactation period (0.014 ppm Se).

\begin{tabular}{lr}
\hline Barley meal & $34.0 \%$ \\
Oat meal & $34.0 \%$ \\
Pease meal & $25.0 \%$ \\
Skimmed milk powder & $4.0 \%$ \\
Basal mineral mixture & $3.0 \%$ \\
\hline
\end{tabular}

Table 2. Basal mineral mixture $(\mathrm{g} / \mathrm{kg})$. The chemicals are feed grade quality.

\begin{tabular}{lc}
\hline $\mathrm{CaHPO}_{4} \mathrm{2H}_{2} \mathrm{O}$ & 500.00 \\
$\mathrm{CaCO}_{3}$ & 360.0 \\
$\mathrm{NaCl}$ & 130.0 \\
$\mathrm{FeSO}_{4}$ & 4.0 \\
$\mathrm{ZnO}$ & 3.0 \\
$\mathrm{MnO}$ & 1.0 \\
$\mathrm{~S}(99 \%)$ & 1.0 \\
$\mathrm{CuO}$ & 0.6 \\
$\mathrm{CoSO}$ & \multicolumn{2}{c}{0.1} \\
$\mathrm{KJ}$ & 0.1 \\
Vitamin $\mathrm{A}$ & $166660 \mathrm{IU}$ \\
Vitamin $\mathrm{D}_{3}$ & $16660 \mathrm{IU}$ \\
Vitamin E & $1333 \mathrm{IU}$ \\
\hline
\end{tabular}

At the age of 1-3 days the live piglets of each litter were divided in 2 parts, the experimental piglets $(n=54)$ and the controls $(n=54)$. A venous blood sample was drawn from each piglet using vacuum tubes containing $0.38 \mathrm{mmol} / 1$ of $\mathrm{K}_{3}$-EDTA. The blood sampling was repeated after 7, 14 and 28 days. The piglets were weighed at weekly intervals. The number of piglets which remained alive during the 4 weeks was 93 (49 and 44 in the experimental and control group, respectively). Immediately after the first blood sampling the piglets of the experimental group were treated subcutaneously with $2 \mathrm{ml}$ of Pigfer-Se vet. inject (Orion Corporation Ltd., Orion Pharmaceutica, Espoo, Finland), which contains $100 \mathrm{mg} \mathrm{Fe}{ }^{+3}$ from iron dextran and $0.15 \mathrm{mg} \mathrm{Se}{ }^{+4}$ from sodium selenite per $\mathrm{ml}$. The control animals were treated similarly with $2 \mathrm{ml}$ of an iron dextran solution containing $100 \mathrm{mg} \mathrm{Fe} \mathrm{e}^{+3}$ per $\mathrm{ml}$ (Pigfer vet. inject., producer as above).

Two weeks after the first treatment each piglet was again treated s.c. with $50 \mathrm{mg} / \mathrm{kg}$ body weight $\mathrm{Fe}^{+3}$ (Pigfer vet. inject.). No creep feed was given to the piglets during the study. Because of the large daily fluctuations of the PCV, RBC and blood volume of neonatal piglets (Balsbaugh et al. 1986) the piglets with a decrease in the RBC during the first week of experiment were excluded from the study. The number of piglets which hence remained in the study throughout the 4 week experimental period was 29 in the experimental group and 34 in the control group.

\section{Analyses of the blood samples}

An aliquot of the blood samples was centrifuged and the plasma separated for the determination of the glutathione peroxidase (GSHPx, EC 1.11.1.9) with a coupled test system according to Günzler et al. (1974) as modified by Sankari (1985). 
The rest of the blood samples were analysed for the number of erythrocytes (RBC) and packed cell volume (PCV) using an electronic blood cell counter (Coulter counter, Model ZF, Coulter Electronics Ltd., England). The Se concentrations of the whole blood and feed samples were determined by a fluorometric method (Lindberg 1968) using $\mathrm{Se}^{75}$ to count the recovery percentage in each sample. NBS bovine liver (U.S. Department of Commerce, National Bureau of Standards, Office of Standard Reference Materials, Washington D.C.) was used to control the accuracy of the Se analyses. The mean Se content of the control liver, calculated from ten successive series of Se determinations, was $1.086(\mathrm{SD}=0.051) \mu \mathrm{g} / \mathrm{g}$ dry weight. The reference Se value for the control liver was stated to be $1.1(\mathrm{SD}=0.1) \mu \mathrm{g} / \mathrm{g}$ dry weight.

\section{Results and discussion}

The results of weighing and of the blood analyses of the experimental and the control groups are given in Table 3.

Figs. 1 and 2 show the distribution of the whole blood Se concentrations at the age of 1-3 days of the experimental $(n=29)$ and

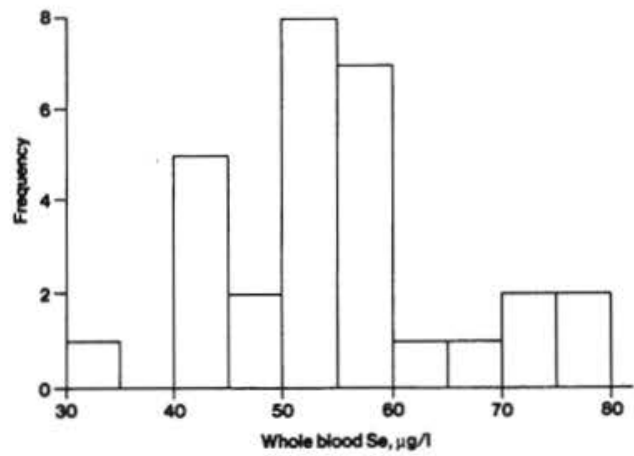

Figure 1. The histogram of the whole blood Se concentration of 29 experimental piglets at the age of 1-3 days.

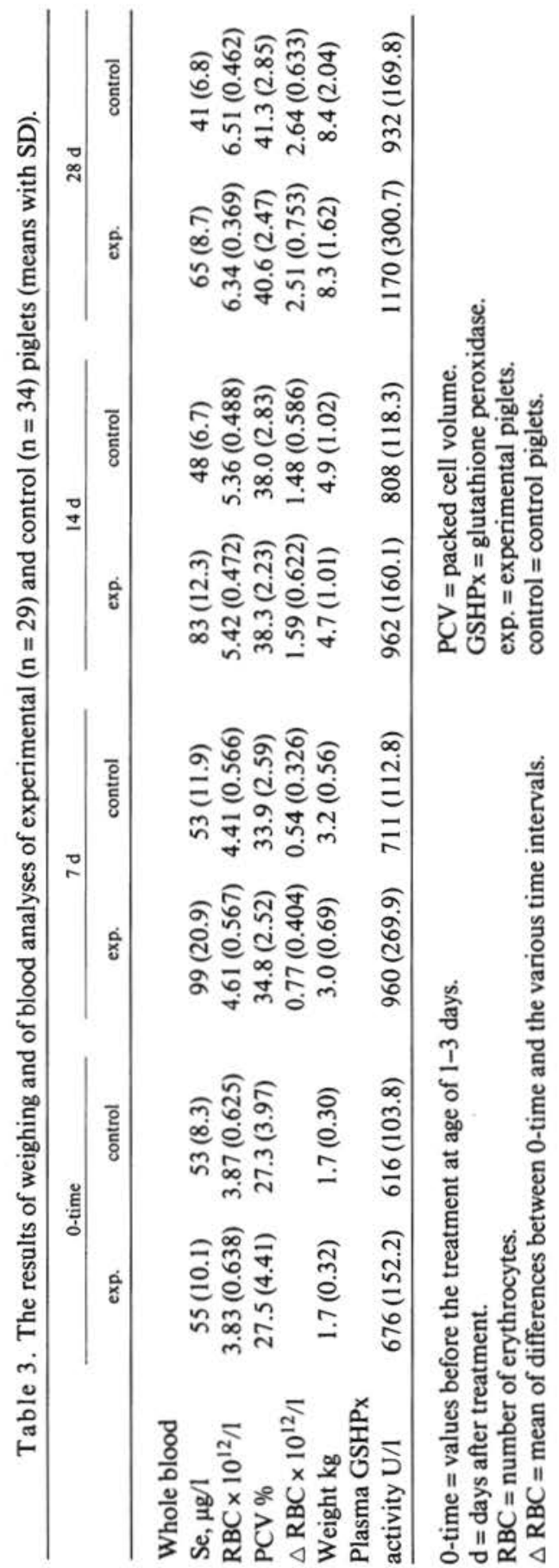




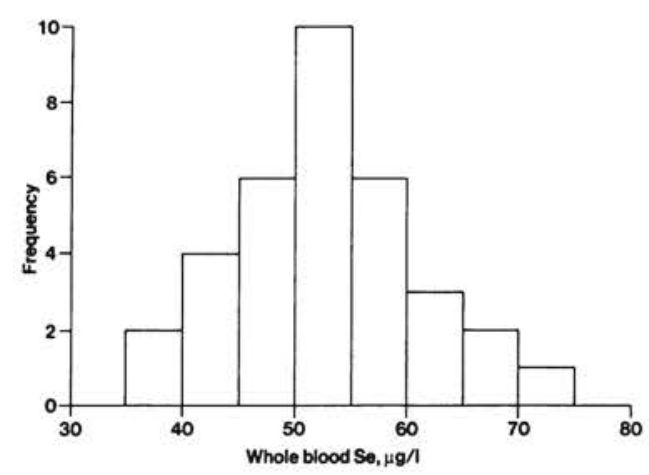

Figure 2. The histogram of the whole blood Se concentration of 34 control piglets at the age of 1-3 days.

control $(n=34)$ piglet respectively. In spite of the low Se level of the feed of sows, the range of the Se concentrations is relatively wide with highest values up to $80 \mu \mathrm{g} / \mathrm{l}$.

Fig. 3 shows the mean whole blood Se va- lues of the experimental and control groups at the various time intervals during the study. The mean Se values as well as the mean plasma GSHPX-activities (Table 3) of the experimental group remained higher than the corresponding means of the control group throughout the study. Although the whole blood Se concentration of the control piglets remained at the initial level during the 4 weeks, the mean plasma GSHPx-activity increased from the 0 -time $676 \mathrm{U} / 1$ to $932 \mathrm{U} / \mathrm{l}$. According to the determination method the increase is in Se dependent GSHPx-activity. It is to be noted that no creep feed was offered to the piglets during the study.

A statistically significant $(\mathrm{p}=0.006$, one tailed t-test) increase in the RBC was observed during the first 7 days of the experiment in piglets of the group treated with Pigfer-Se as compared to the piglets treated

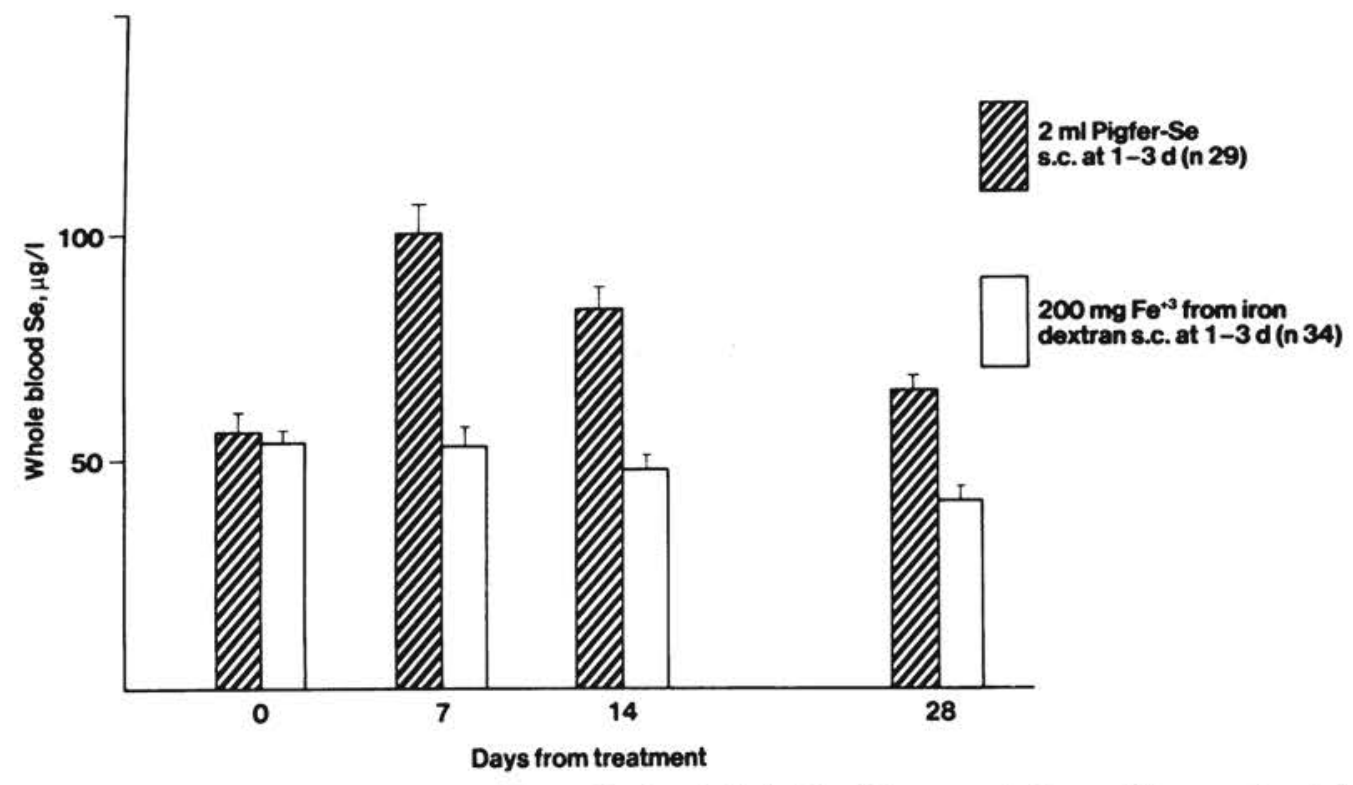

Figure 3. The means and $95 \%$ confidence limits of whole blood Se concentrations of the experimental $(\mathrm{n}=29)$ and control $(\mathrm{n}=34)$ piglets $0,7,14$ and 28 days after treatment with Pigfer-Se or iron dextran only. 


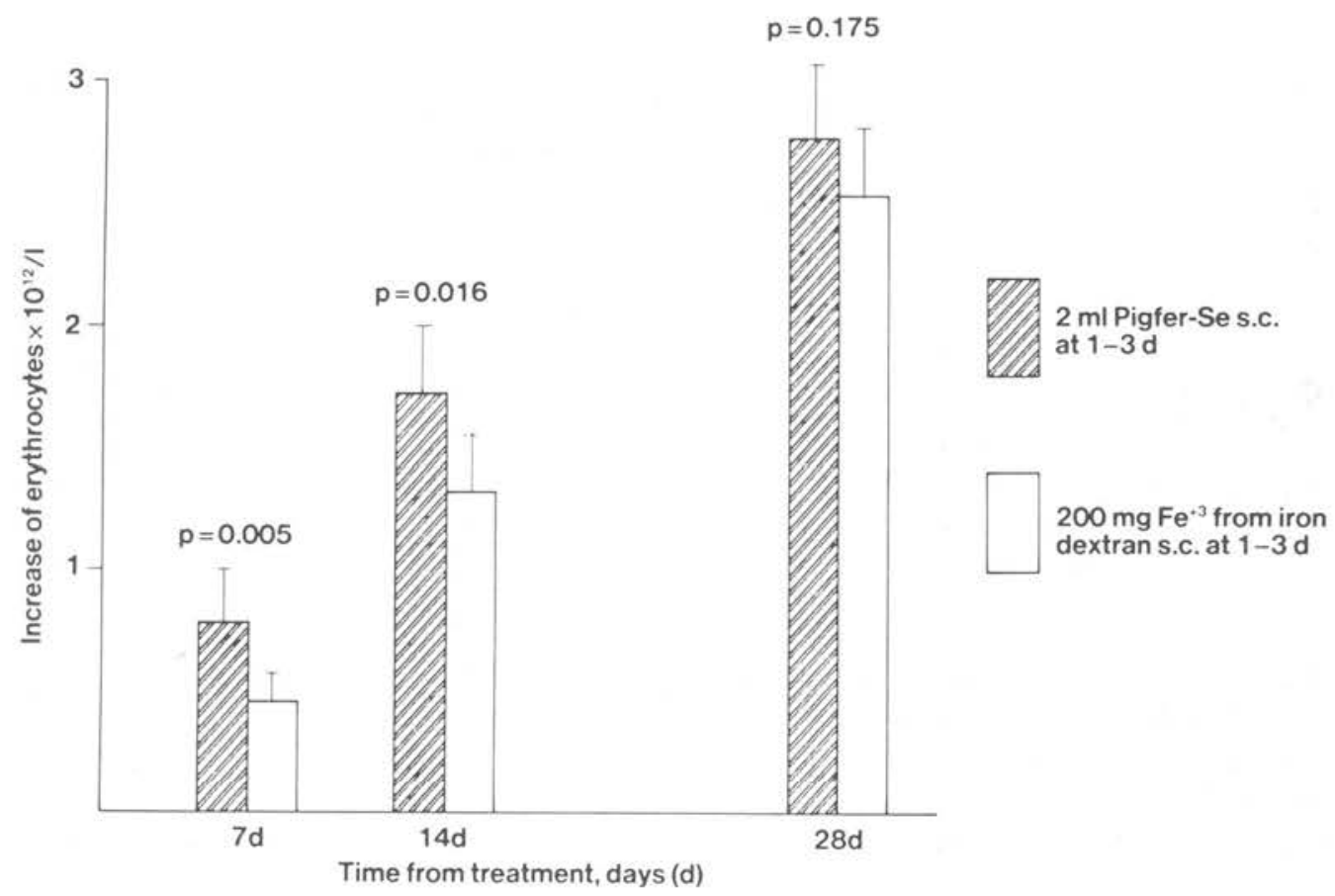

Figure 4. The mean increase in RBC (mean and $95 \%$ confidence limit) of experimental $(n=16)$ and control $(\mathrm{n}=22)$ piglets 7,14 and 28 days after treatment with whole blood Se at $1-3$ days $\leqq 55 \mu \mathrm{g} / \mathrm{l}$. $\mathrm{p}=$ critical level of the one-sided $\mathrm{t}$-test.

with Fe dextran only. No other statistically significant differences between the groups could be observed at the successive samplings.

When only such piglets of the experimental and the control group with the initial whole blood Se $\leqq 55 \mu \mathrm{g} / \mathrm{l}(\mathrm{n}=16$ and $\mathrm{n}=22$ respectively) were similar compared, (Fig. 4), a statistically significantly larger mean increase in RBC was observed in the experimental group during the first 7 days $(\mathrm{p}=$ $0.005)$ and the 14 days $(p=0.016)$ than in the control group. At 28 days the difference between the means was not significant $(\mathrm{p}=$ 0.175).

The results indicate that combined $\mathrm{Fe}-\mathrm{Se}$ treatment increases the erythropoiesis of newborn piglets born to sows kept on a low
Se diet during the last month of gestation and especially of those piglets with whole blood $\mathrm{Se} \leqq 55 \mu \mathrm{g} / \mathrm{l}$ when compared to $\mathrm{Fe}$ treatment only. This observation confirms the results of previous studies which suggested a role for $\mathrm{Se}$ in the haematopoiesis of piglets (Pekkanen et al. 1987, Sankari 1985).

Because of the probable genetic factors which in addition to Se level in feed largely determine the Se status of pigs and their offsprings (Stowe \& Miller 1985), it seems justified to treat all newborn piglets with $\mathrm{Fe}$ and Se instead of iron only.

The mean weekly weight gains of the experimental and control piglets with 1-3 days whole blood Se $\leqq 55 \mu \mathrm{g} / 1$ is illustrated in Fig. 5. 


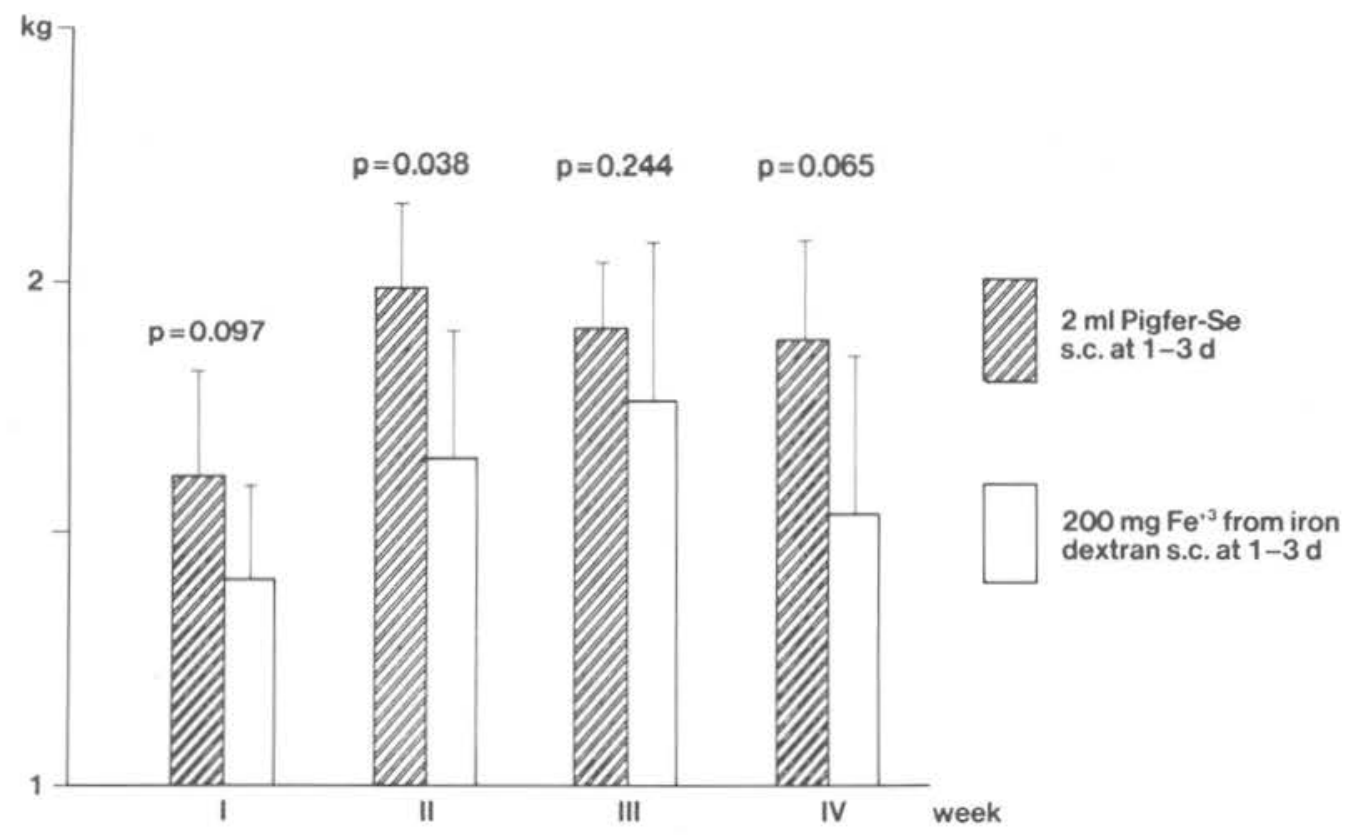

Figure 5. The mean weekly weight gains (mean and $95 \%$ confidence limit) of experimental $(n=16)$ and control $(\mathrm{n}=22)$ piglets with whole blood Se at $1-3$ days $\leqq 55 \mu \mathrm{g} / \mathrm{l} . \mathrm{p}=$ critical level of the one-sided $\mathrm{t}$-test.

The results show that the combined Fe-Se treatment of neonatal relatively hyposelenic pigs is superior to $\mathrm{Fe}$ treatment. This also pertains to weight development during the first few weeks of life. The positive effect of Se supplementation to the development of weight of hyposelenic pigs has recently been noted by Stowe \& Miller (1986).

\section{References}

Balsbaugh RK, Curtis SE, Meyer RC: Body weight, total body water and haematocrit in diarrheic piglets. J. Anim. Sci. 1986, 62, 307314.

Günzler, WA, Kremers $H$, Flohe L: An improved coupled test procedure for glutathione peroxidase (EC 1.11.1.9.) in blood. Klin. Chem. Klin. Biochem. 1974, 12, 444-448.

Lindberg, $P$ : Selenium concentration in plant and animal material and in water. A methodological study. Acta vet. scand. Suppl. 23, 1968.

Pekkanen $T$, Lindberg $P$, Sankari S: The effect of Se status on some haematological parameters of neonatal piglets. Internat. J. Vit. Nutr. Res. 1987,57 , in press.

Sankari S: Plasma glutathione peroxidase and tissue selenium response to selenium supplementation in swine. Acta vet. scand. Suppl. 81, 1985, p. 1-127.

Stowe HD, Miller ER: Genetic predisposition of pigs to hypo- and hyperselenemia. J. Anim. Sci. 1985, 60,200-211. 


\section{Sammendrag}

Effekten av kombinerad järn-selen behandling på erytropoies och viktutveckling hos smågrisar.

Tio suggor hölls på selenfattigt foder $(0.014 \mathrm{mg} / \mathrm{kg}$ Se) under den sista dräktighetsmånaden och de fyra första laktationsveckorna. Deras 1-3 dygn gamla grisar (108) indelades i 2 grupper, en försöks- och en kontrollgrupp. Blodprov togs från grisarna före 3 dagars ålder. Varje gris i försöksgruppen (54) behandlades subkutant i samband med blodprovstagningen med $200 \mathrm{mg} \mathrm{Fe}{ }^{+3}$ som järndextran och $0.30 \mathrm{mg} \mathrm{Se}^{+4}$ som natriumselenit (Pigfer-Se, Orion corporation Ltd, Orion Pharmaceutica, Esbo, Finland). Kontrollgruppens grisar (54) behandlades på motsvarande sätt med $200 \mathrm{mg}$ $\mathrm{Fe}^{+3}$ som järndextran. Blodprov togs på nytt 7,14 och 28 dagar efter den första provtagningen.

Resultaten visade att den genomsnittliga ökningen av antalet röda blodkroppar under de sju första dagarna var signifikant större $\mathrm{i}$ försöksgruppen jämfört med kontrolgruppen $(P=0.006)$. Inga signifikanta skillnader mellan grupperna kunde observeras vid senare blodprovstagningar.

Vid jämförelse av några hematologiska parametrar hos sådana grisar i försöks- och kontrollgruppen som före tre dagars ålder hade $\leqq 55 \mu \mathrm{g} / 1$ selen $\mathrm{i}$ helblod ( 16 respektive 22 grisar) fann man att den genomsnittliga ökningen av röda blodkroppar var signifikant högre i försöksgruppen än i kontrollgruppen både 7 och 14 dagar efter experimentets början ( $P=0.005$ resp. $P=0.016$ ). Vid 28 dagar var skillnaden mellen medeltalen inte signifikant. Medelviktökningen per vecka hos grisarna med låga Se-värden $\mathrm{i}$ försöksgruppen var hela tiden högre än medelviktökningen hos grisarna $\mathrm{i}$ kontrollgruppen.

(Received November 10, 1986).

Reprints may be requested from: T. Pekkanen, College of Veterinary Medicine, P. O. Box 6, SF-00551 Helsinki, Finland. 